\title{
SANKSI PENYEBAR HOAX PERSPEKTIF HUKUM PIDANA ISLAM
}

\author{
Wahyu Abdul Jafar \\ Fakultas Syariah IAIN Bengkulu \\ Jln. Raden Fatah Pagar Dewa Kota Bengkulu \\ Email: wahyujabar@gmail.com
}

\begin{abstract}
This study discusses the issue of hoaxes which have been troubling the community. One reason for the rise of hoax news is that the handling is only from the side of positive law without involving religious elements, whereas religious teachings are very effective for preventive actions because if there are religious elements in the handling, people will always be watched and afraid of sinning if they violate. The subject of this study is how to set ta'zir sanctions for hoax makers and disseminators in the perspective of Islamic law. This study is included in the literature research category, while the approach used in this study is a normative approach. The data collection technique used is documentation technique. After an in-depth study was obtained a conclusion that there were three categories of ta'zir sanctions, namely minor, moderate and severe sanctions. Minor sanctions are given to perpetrators and disseminators of hoaxes with motives of ignorance and victims of technological and information developments. While giving sanctions is being given to the perpetrators and disseminators of the hoax with the motive for the absence of legal certainty. Then hoax makers and spreaders who have motives for malicious intentions and politics are given the heaviest sanctions.
\end{abstract}

Keywords: Islamic Law; Hoax; Istinbath Ahkam

\begin{abstract}
Abstrak: Kajian ini membahas tentang persoalan hoax yang selama ini meresahkan masyarakat. Salah satu penyebab maraknya berita hoax adalah penangananya hanya dari sisi hukum positif saja tanpa melibatkan unsur agama, padahal ajaran agama sangat efektif sekali untuk tindakan preventif karena jika ada unsur agama didalam penangananya maka orang akan selalu merasa diawasi dan takut berdosa jika melangar. Pokok bahasan dalam kajian ini adalah bagaimana implementasi istinbath ahkam pada sanksi penyebar berita hoax. Penelitian ini termasuk kategori penelitan pustaka, sedangkan pendekatan yang digunakan dalam penelitian ini adalah pendekatan normatif. Teknik pengumpulan data yang dipergunakan adalah teknik dokumentasi. Setelah dilakukan kajian mendalam diperoleh sebuah kesimpulan bahwa Ada tiga katogori dalam pemberian sanksi ta'zir, yakni sanksi ringan, sedang dan berat. Sanksi ringan diberikan kepada pelaku dan penyebar hoax dengan motif ketidaktahuan dan korban perkembangan teknologi dan informasi. Sedangkan pemberian sanksi sedang diberikan kepada pelaku dan penyebar hoax dengan motif tidak adanya ketegasan hukum. Kemudian pembuat dan penyebar hoax yang memiliki motif adanya niat jahat dan politik diberikan sanksi terberat.
\end{abstract}

Kata kunci: Fiqh, Hoax, Istinbath Ahkam

\section{Pendahuluan}

Hoax saat ini menjadi ancaman yang sangat serius dalam memecah belah persatuan bangsa. Rakyat yang tadinya hidup dalam damai berdampingan meskipun dari berbagai latar belakang yang berbeda bisa menjadi terpecah belah bahkan tidak jarang menimbulkan kerusahan akibat tersebarnya hoax ditengah tengah masyarakat. Tujuan disebarkannya hoax ditengah masyarakat memang untuk membuat kegaduhan dan kekacawan, sehinga hoax sangat berbahaya sekali. Oleh sebab itu, perlu diberikan sanksi yang tegas baik bagi pembuat berita hoax itu sendiri maupun pihak pihak yang sengaja menyebarkan berita hoax tersebut.

Apabila terjadi pembiaran berita hoax tanpa ada tindakan tegas maka penyebaran berita hoax akan semakin merajalela apalagi di tahun politik seperti saat ini. Berita berita hoax berseliweran semakin banyak beredar didunia maya karena ada pihak pihak tertentu yang memanfaatkanya demi merauk kepentingan politik dan ekonomi. 
Menurut data yang direlease dari website Kemenkominfo ada sekitar kurang lebih 800.000 situs di Indonesia yang telah terindikasi sebagai penyebar berita hoax. Berita berita hoax ini sengaja disebarkan melalui internet dengan tujuan mendapatkan keuntungan pribadi dan kelompoknya. ${ }^{1} \mathrm{Hal}$ senada juga disampaikan oleh Direktur Informasi dan Komunikasi Badan Intelijen Negara (BIN) Wawan Purwanto, ia menyebut bahwa konten-konten media sosial yang ada di Indonesia ternyata didominasi oleh informasi bohong alias hoax, dari hasil penelitian yang diperoleh sekitar $60 \%$ konten media sosial di Indonesia berisi informasi hoax. ${ }^{2}$

Kondisi ini diperparah juga dengan banyak warga indonesia belum memiliki pengetahuan dan sumber yang cukup, untuk membedakan informasi atau berita yang diperolehnya benar atau salah. Sehinga berita yang didapat dari media sosial langsung dipercaya tanpa ada kroscek terlebih dahulu.

Menurut Amir Karimuddin (Chief Editorial \& Research of DailySocial.id), setelah melakukan Riset yang mendalam diperoleh hasil yang mengejutkan bahwa sekitar 44\% Masyarakat Indonesia tidak bisa mendeteksi berita hoax. ${ }^{3}$ Hal ini disebabkan daya kritis masyarakat indonesia yang lemah sehinga mudah percaya apa saja yang beredar didunia maya apalagi jika diperkuat dengan adanya vidio atau foto, padahal dengan perkembangan teknologi yang semakin cangih saat ini, vidio dan foto bisa direkayasa dan diedit sedemikan rupa mengikuti keinginan orang yang membuatnya.

1 https://kominfo.go.id/content/detail/12008/ada800000-situs-penyebar-hoax-di-indonesia/0/sorotan_media, didownloud pada tanggal 7 januari 2019

${ }^{2}$ Artikel ini telah tayang di Kompas.com dengan judul "BIN: 60 Persen Konten Media Sosial adalah Informasi Hoaks", https://nasional.kompas.com/read/2018/03/15/06475551/ bin-60-persen-konten-media-sosial-adalah-informasi-hoaks. Penulis: Ambaranie Nadia Kemala Movanita, Editor: Diamanty Meiliana. Didownloud pada tanggal 7 Januari 2019

3 Artikel ini telah tayang di bangkapos.com dengan judul, http://bangka.tribunnews.com/2018/09/13/hasil-risetdailysocialid-44-masyarakat-indonesia-tidak-bisa-mendeteksiberita-hoax. Editor: Ardhina Trisila Sakti. Didownloud pada tanggal 7 Januari 2018
Fenomena ini tentu membutuhkan perhatian dan penangan khusus dari berbagai pihak berwenang untuk mengatasi problem penyebaran hoax yang semakin masif. Oleh sebab itu, peneliti berusaha ikut memberikan sumbangsih penanganan penyebaran hoax dari sisi hukum Islam yaitu berupa penawaran pemberian sanksi tázir kepada pembuat dan penyebar berita hoax. Maka rumusan masalah dalam penelitian ini adalah bagaimana sanksi penyebar hoax dalam istinbath ahkam?

\section{Metode Penelitian}

Penelitian ini jika dilihat dari sisi tempat dilakukanya penelitian maka termasuk jenis penelitian kepustakaan (library research) ${ }^{4}$, sedangkan penelitian ini jika dilihat dari sisi paradigma penelitian, maka penelitian ini termasuk jenis penelitian kualitatif. Sumber data dalam penelitian ini, ada beberapa sumber $\mathrm{se}^{-}$ bagai bahan rujukan, antara lain: pertama, sumber data primer dalam penelitian ini adalah kitab kitab dan buku buku yang berkaitan langsung dengan obyek yang sedang peneliti kaji, yakni kitab dan buku buku yang berkaitan dengan ta'zir dan hoax. Kedua, sumber data sekunder yaitu sumber yang secara tidak langsung berkaitan dengan objek penelitian ini dan dirasa sangat mendukung dalam suksesnya penelitian ini.

Selanjutnya, teknik pengumpulan data dalam penelitians ini adalah dokumentasi. Yang diamaksud dengan teknik dokumentasi adalah

\footnotetext{
4 Jenis penelitian bisa dilihat dari beberapa sudut pandang, yang pertama menurut bidangnya terbagi atas penelitian pendidikan, penelitian sejarah, penelitian bahasa, dan sebagainya. Yang kedua menurut tempatnya terbagi atas penelitian laboratorium, penelitian perpustakaan dan penelitian kancah. Yang ketiga berdasarkan penggunaannya terbagi atas penelitian murni dan penelitian terapan. Yang keempat menurut tujuan umumnya terbagi atas penelitian eksploratif, penelitian developmental dan penelitian verivikasi. Yang kelima menurut tarafnya terbagi atas penelitian deskriptif dan inferensial. Yang keenam menurut pendekatannya terbagi atas penelitian longitudinal dan penelitian cross sectional. Yang ketujuh menurut paradigmanya terbagi atas penelitian kuantitatif dan penelitian kualitatif. Moh. Kasiram, Metodologi Penelitian Kualitatif-Kuantitatif, (Malang: UIN-Maliki Press, 2008),. cet. ke-1. h. 53.
} 
Peneliti dalam mengumpulkan data melakukannya dengan cara meneliti terhadap bukubuku, catatan-catatan, arsip-arsip yang berkaitan dengan sanksi penyebar hoax dalam istinbath ahkam. Peneliti memilih teknik dokumentasi karena obyek kajian penelitian yang dilakukan adalah pustaka sehingga cukup mengunakan teknik dokumentasi tanpa mengunakan teknikteknik yang lain.

Adapun teknik analisa data dalam penelitian ini, peneliti mengunakan teknik analisis preskriptif. Teknik analisis preskriptif digunakan oleh peneliti untuk menjawab rumusan masalah "bagaimana implementasi istinbath ahkam pada sanksi penyebar berita hoax". Selanjutnya dalam menganalisis data, Peneliti melakukan empat tahapan, sebagaimana berikut: Pertama, data yang telah diklasifikasikan disaring ulang dengan merujuk kepada teknik pengumpulan data (dokumentasi). Kedua, memahami masing-masing kelas dan subkelas data melalui cara penafsiran data berdasarkan pendekatan logis (perpaduan deduktif-induktif dengan mengikuti data). Ketiga, menghubungkan antar kelas dan subkelas data yang telah dipahami. Keempat, mendeskripsikan apa yang diperoleh dari tahap ketiga dengan tetap merujuk kepada kerangka analitis, sehinga hasil penelitian dapat dideskripsikan dan selanjutnya dapat ditarik kesimpulan internal untuk menjawab pertanyaan penelitian. ${ }^{6}$

\section{Kajian Teori}

Secara garis besar, jenis-jenis hukuman dalam pidana Islam terdiri dari qishâs-diyat, kafârat, hudûd, dan ta'zîr. Keempat jenis hukuman ini mempunyai bentuk yang bervariasi sesuai dengan perbedaan macam tindak pidana yang diancamnya. Qishâs-diyat yang berkaitan dengan

5 Analisis Preskriptif adalah teknik analisis mengunakan pendekatan normatif, yakni dari sudut pandang ushul fiqh dengan mengaplikasikan teori istinbāṭ al-aḥkām. Cik Hasan Bisri, PilarPilar Penelitian Hukum Islam dan Pranata Sosial, (Jakarta: PT. Raja Grafindo Persada, 2004). cet. ke-1, h. 404-305.

${ }^{6}$ Cik Hasan Bisri, Model Penelitian Fiqh, (Bogor: Kencana, 2003), cet. ke-1. h. 96-98. kejahatan terhadap jiwa dan anggota tubuh, bervariasi sesuai dengan bentuk kejahatannya. Begitu pula dengan hudûd, bentuk-bentuknya adalah hukuman mati, hukuman potong (tangan atau kaki), dera (cambuk, jild), rajm (dilempari pakai batu hingga mati) dan pengasingan. Sedangkan hukuman tázîr memiliki bentuk paling beragam, karena penetapan bentukbentuknya merupakan wewenang hakim. ${ }^{7}$

\section{Teori Ta'zir}

Secara bahasa ta'zir berarti menolak atau mencegah. Sedangkan secara istilah, ta'zir adalah bentuk hukuman yang tidak disebutkan ketentuan kadar hukumanya oleh syara' dan menjadi kekuasaan waliyyul amri atau hakim. ${ }^{8}$

Sedangkan Wahbah Az-Zuhaili dalam kitab Figh Islami menerangkan bahwa yang disebut ta'zir adalah sebagai berikut:

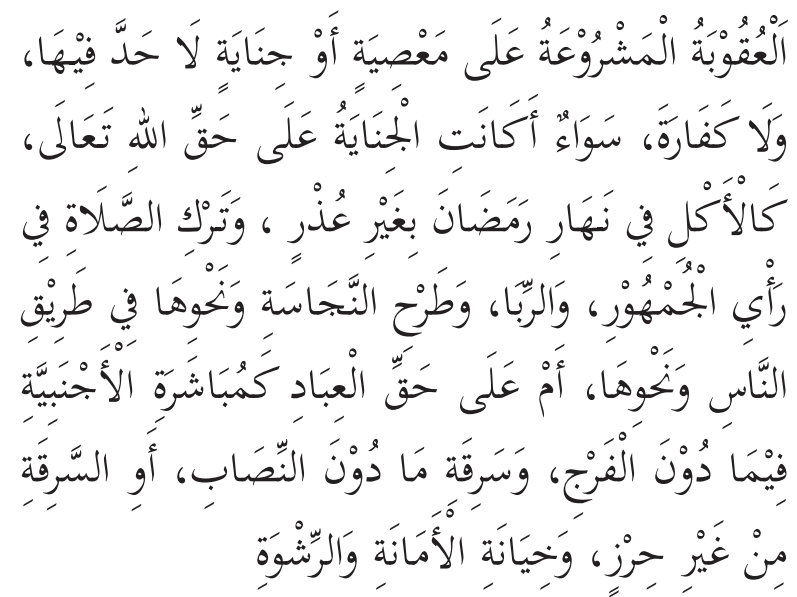

Hukuman-hukuman yang dibuat atas perbuatan maksiat atau perbuatan pidana yang tidak ada had dan kafarotnya, baik tindak pidana yang berkaitan dengan hak Allah Swt. Seperti berbuka puasa pada bulan romadhon tanpa udzur, meningalkan sholat, makan riba, melemparkan benda najis atau semisalnya kejalan manusia, atau tindak pidana tersebut berkaitan dengan hak manusia, seperti berhubungan badan dengan wanita lain selain farji, mencuri kurang dari satu

${ }^{7}$ Toha Andiko, "Reinterpretasi Sanksi Pidana Islam (Studi terhadap Pemikiran Prof. KH. Ibrahim Hosen”, LML), Madania: Jurnal Kajian Keislaman, Vol. 18, No. 2, (2014), h. 235.

${ }^{8}$ Rahmat Hakim, 2000. Hukum Pidana Islam. (Bandung: CV Pustaka Setia, 2016), cet. ke-1. h.141. 
nishob, mencuri tidak pada tempatnya, menyianyiakan amanat dan menyuap. ${ }^{9}$

Secara garis besar ta'zir terbagi menjadi dua, yaitu: ${ }^{10}$

Pertama, Ta'zir Syara', yaitu ta'zir yang penentuan jarimahnya berasal dari syara' tetapi syara' tidak menentukan apa bentuk hukumannya. Misalnya ta'zir makan makanan yang telah diharamkan oleh Alquran seperti darah, bangkai, daging babi, dan lain-lain. Sebagaiman firman Allah dalam surat al-Baqarah ayat 173:

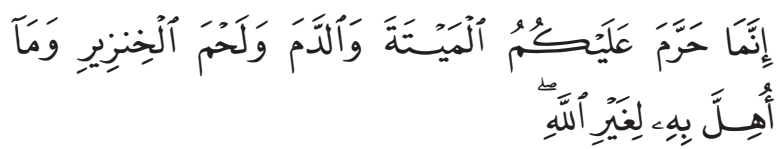

Sesungguhnya Allah hanya mengharamkan bagimu bangkai, darah, daging babi, dan binatang yang (ketika disembelih) disebut (nama) selain Allah.

Syara' dalam hal ini tidak menyebutkan apa bentuk hukuman dari pelangaran ini, akan tetapi syara' hanya menentukan bahwa perbuatan ini adalah perbuatan yang dilarang oleh syara'.

Kedua, Tázir Penguasa, ta'zir yang bersifat temporer dan insidentil, maksudnya seorang penguasa dalam satu kondisi tertentu bisa menjatuhkan hukuman ta'zir tersebut tapi pada kondisi yang lain bisa saja penguasa tidak menjatuhkan ta'zir karena ada maslahat. Hal ini berbeda dengan ta'zir syara' yang sifatnya abadi tidak bisa berubah-ubah. Contoh dari tazir jenis ini adalah pengaturan lalu lintas. Jalan dibuat untuk dipakai, baik oleh pejalan kaki atau pemakai kendaraan dan berjalan itu sendiri (termasuk mengunakan kendaraan) adalah sesuatu yang legal. Namun, pada jalur jalur tertentu, berjalan (memasuki ruas jalan) dianggap sebagai sesuatu yang dilarang yang ditandai dengan rambu rambu tertentu. Pelarangan tersebut pasti berkaitan dengan kepentingan dan ketertiban, misalnya ruas jalan tersebut dipakai sebagai tempat sidang atau pertemuan penting. Hal ini bersifat sementara

\footnotetext{
9 Wahbah al-Zuhaili. Figh al-Islam wa Adillatuhu, (Damaskus: Dar al-Fikr, t.th), cet. ke-14, Jilid 7, h. 514.

${ }^{10}$ Rahmat Hakim. Hukum Pidana Islam, (Bandung: CV Pustaka Setia, 2010), cet. ke-1. h 142-151.
}

sebab apabila pameran atau pertemuan tersebut sudah selesai, jalan tersebut akan dibuka kembali untuk umum. Hal ini karena kepentingan umum menghendaki dibukanya kembali jalan tersebut.

\section{Tujuan Penjatuhan Ta'zir}

Hukum ta'zir dilihat dari segi penjatuhanya terbagi dalam beberapa tujuan, antara lain: ${ }^{11}$

Pertama, hukuman ta'zir sebagai hukuman tambahan atau pelengkap hukuman pokok. Contoh, hukuman pengasingan selama satu tahun dalam kasus pezina gair mubshan menurut mazhhab Hanafi merupakan contoh bentuk hukuman tambahan, yang mengiringi hukuman pokok seratus kali jilid pada jarimah hudud. Kedua, hukuman ta'zir sebagai penganti hukuman pokok. Hal ini terjadi karena misalkan bukti bukti yang terkumpul kurang meyakinkan atau ada keraguan (syubhat) menurut penilaian hakim. Sebagaimana bunyi kaidah: hindari (penjatuhan) bukuman had (karena) adanya kesamaran (syubhat). Hukuman pokok pada hal-hal (kekurangan bukti dan syubhat) tersebut tidak boleh dijatuhkan karena dengan kedua alasan tersebut, status jarimah berpindah dari hudud atau qishash menjadi jarimah ta'zir. Ketiga, hukuman ta'zir sebagai hukuman pokok bagi jarimah ta'zir syara'. Misalnya ta'zir bagi orang yang memakan makanan yang diharamkan.

\section{Unsur-Unsur Tindak Pidana Hoax Dalam Islam}

Untuk menentukan jenis sanksi, tentu harus sesuai dengan kaidah-kaidah hukum Islam yang sejalan dengan prinsip untuk memelihara stabilitas hidup bermasyarakat, sehingga berat dan ringannya sanksi hukum harus disesuaikan dengan jenis tindak pidana yang dilakukan, disesuaikan dengan lingkungan di mana pelanggaran itu terjadi, dikaitkan dengan motivasimotivasi yang mendorong sebuah tindak pidana dilakukan. $^{12}$

\footnotetext{
${ }^{11}$ Rahmat Hakim, Hukum Pidana Islam. h 143.

12 Toha Andiko, "Sanksi Bagi Pemberi Dan Penerima Gratifikasi Perspektif Hukum Pidana Islam”, Jurnal Qiyas, Vol. 1, No. 1 (2016), h. 127.
} 
Dalam pidana Islam sendiri, pintu pemberian sanksi terhadap tindak pidana bisa dilakukan dengan dua cara, yakni pintu had dan pintu ta'zir. Tindak pidana yang penjatuhan sanksinya melalui pintu had ialah bagi tindak pidana yang aturan hukumnya sudah diberikan secara jelas didalam Alquran dan hadis. Sedangkan tindak pidana yang diberikan ta'zir ialah bagi tindak pidana yang persoalan sanksi hukumnya belum diatur secara jelas baik didalam Alquran maupun hadis. Sehinga bila dilihat dari konteks ini maka pemberian sanksi bagi pembuat dan penyebar hoax adalah melalui pintu ta'zir yang bentuk dan kadar pemberian sanksinya diserahkan sepenuhnya kepada hakim.. Namun, hakim tidak bisa juga sewenang-wenang dalam menjatuhkan hukuman harus mempertimbangkan beberapa apakah perbuatan tersebut sudah memenuhi unsur tindak pidana atau belum.

Seseorang dapat dikatakan melakukan tindak pidana apabila dapat dibuktikan telah melakukan perbuatan perbuatan yang dilarang oleh syara. Setiap tindakan pidana dapat dibuktikan apabila perbuatan tersebut memenuhi unsurunsur sebagai berikut:

Pertama, Unsur Umum, yaitu unsur-unsur yang harus ada pada setiap jarimah (tindak pidana) yang meliputi sebagai berikut:

a) Unsur formil, yaitu adanya nas yang melarang perbuatan-perbuatan tertentu yang disertai ancaman hukuman atas perbuatanperbuatan tersebut.

Hal ini sejalan dengan qoidah,

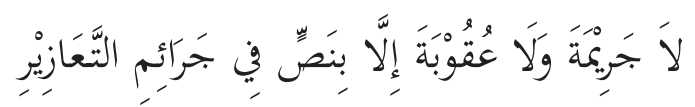

Tidak ada tindak pidana dan hukuman kecuali sudah ada aturanya (nashnya) dalam masalah tindak pidana ta'zir ${ }^{13}$

b) Unsur materiil, yaitu adanya tingkah laku yang membentuk jarimah (tindak pidana) baik perbuatan yang nyata maupun sikap tidak berbuat.

13 Abd al-Qadir al-Audah, al-Tasyri al-Jinäi al-Islami, Maktabah Syamilah Versi 7 G \& 14 G, Jilid 1. h. 133. c) Unsur moril, yaitu adanya kemampuan atau kecakapan bertanggung jawab terhadap jarimah (tindak pidana) yang diperbuatnya.

Hal ini selaras dengan qoidah,

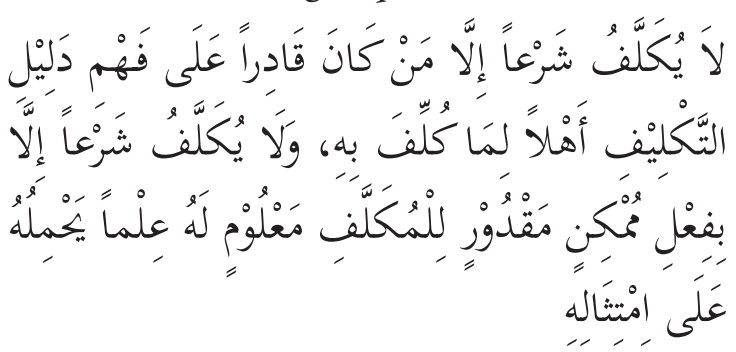

Orang tidak dibebani aturan secara syara' kecuali ia mampu untuk memahami aturan tersebut dan ia termasuk cakap (layak) hukum dan ia juga tidak dibebani secara syara' kecuali pada perbuatan-perbuatan yang dimampui dan diketahui yang bisa mengantarkan perbuatan tersebut untuk dipatuhi. ${ }^{14}$

Kedua, Unsur Khusus, yaitu unsur-unsur yang hanya ada pada jinayah tertentu dan unsur itu selalu berbeda jumlahnya dan jenisnya sesuai dengan perbedaan jarimahnya, seperti unsur mengambil secara diam-diam tersebut hanya diperlakukan pada jarimah mencuri tidak pada jarimah lainnya. Demikian juga unsur bersetubuh hanya ada pada jarimah zina dan unsur bersetubuh tersebut hanya diberlakukan pada jarimah zina tidak pada jarimah lainnya.

Perbedaan antara unsur umum dan unsur khusus terletak pada keberadaan unsur-unsur tersebut pada setiap jarimah. Oleh sebab itu, suatu perbuatan dapat dikatakan sebagai perbuatan jarimah dan dapat dijatuhi hukuman apabila perbuatan tersebut telah memenuhi unsur umum dan unsur khusus. Dalam unsurunsur tersebut terdapat pengecualian dalam tanggung jawab hukum, diantaranya:

a) Orang gila sampai ia sadar

b) Anak-anak sampai usia puber

c) Orang yang tidur sampai ia bangun. ${ }^{15}$

\footnotetext{
${ }^{14}$ Abd al-Qadir al-Audah, al-Tasyri al-Jinäi al-Islami, h. 123.

${ }_{15}$ Di sisi lain, ketidak tahuan pelaku juga berpengaruh terhadap pertanggung jawaban pidana. Artinya, seseorang yang melakukan tindak pidana akan dihukum jika ia benarbenar mengetahui bahwa tindakan tersebut memang dilarang.
} 


\section{Pengertian Hoax dan Jenisnya Yang Populer di Masyarakat}

Istilah hoax dalam bahasa indonesia sering disebut dengan 'hoaks' yang bisa diartikan sebagai 'berita bohong atau berita yang tidak memiliki sumber jelas. ${ }^{16}$ Sedangkan dalam kamus Oxford English dictionary, istilah 'hoax' didefinisikan sebagai 'malicious deception' atau 'kebohongan yang dibuat dengan tujuan jahat'. Dari sini dapat diketahui bahwa hoax adalah berita bohong yang tidak bisa dipertangung jawabkan kebenarannya dan berita bohong ini dibuat dengan tujuan tidak baik. Hoax berisi informasi yang memang sengaja disesatkan (tidak benar), namun informasi ini "dijual" sebagai kebenaran. ${ }^{17}$

Istilah lain yang hampir mirip dengan hoax adalah fake news (berita bohong). Antara hoax dengan fake news memang memiliki banyak persamaan namun ada perbedaan diantara keduanya. Perbedaan terletak pada fakta yang melandasi berita atau informasi yang dibuat. Jika berita yang dibuat tersebut ternyata berita bohong, berita buatan atau berita palsu yang sama sekali tidak dilandaskan dengan fakta, kenyataan atau kebenaran maka berita tersebut disebut dengan fake news. Contoh fake news adalah ada sebuah berita yang menyebutkan telah terjadi tsunami didaerah medan pada hari

Pengertian "mengetahui" cukup dengan kemungkinan mengetahui. Sehingga jika seseorang mencapai usia dewasa, berakal serta mudah baginya untuk mengetahui aturan yang berlaku, baik dengan mengkaji atau bertanya kepada orang lain, maka ia telah dianggap mengetahui. Pengakuan seseorang atas ketidaktahuan terhadap hukum hanya bias diterima ketika ia benar-benar tidak mendapatkan akses informasi terkait dengan hukum tersebut. Para ulama sering mencontohkannya, jika ada sekelompok orang yang tinggal di hutan dan tidak pernah berbaur dengan kaum muslimin, maka pengakuan ketidak tahuannya bisa diterima. Namun jika seseorang mengaku tidak tahu sedangkan ia tinggal di keramaian, berbaur dengan orang alim dan mudah mendapatkan akses informasi, maka pengakuannya tidak diterima dan tetap bertanggungjawab dalam hukum. Kajian Teoritis Tentang Hukuman Tindak Pidana Dalam Fiqih Jinayah. h. 19-22.

16 Wijayanti, Sri. "Arti kata Hoax - Kamus Besar Bahasa Indonesia (KBBI) Online”. www.kbbionline.com. Diakses tanggal 7 Januari 2019.

17 Silverman, Craig. (2015).Journalism: A Tow/Knight Report."Lies, Damn Lies, and Viral Content". Columbia Journalism Review (dalam bahasa Inggris). Diakses tanggal 7 Oktober 2018. senin kamaren padahal kenyataanya didaerah medan pada hari senin kemaren tidak terjadi apa apa. Sedangkan jika berita yang dibuat sebenarnya ada faktanya namun telah terjadi rekayasa yang memodifikasi isi berita maka berita atau informasi tersebut masuk kategori hoax. Contoh dari hoax adalah kasus Ratna Sarumpet yang dikabarkan dianiaya oleh orang tak dikenal di Bandung hingga Ratna Sarumpet mengalami luka-luka. Fakta sebenarnya memang Ratna Sarumpaet mengalami luka luka namun bukan akibat dianiaya oleh orang tak dikenal tapi yang sebenarnya luka tersebut akibat operasi plastik yang dilakukan oleh ratna sarumpet di Jakarta. Berita yang sengaja disebar mengenai Ratna Sarumpaet telah mengalami luka-luka akibat operasi adalah benar sesuai fakta, namun berita tersebut dipelintir menjadi luka akibat dianiaya.

Seiring dengan perkembangan waktu, antara istilah hoax dan fake news tidak ada bedanya lagi. Masyarakat menyebut berita yang bohong atau berita rekaya dari fakta yang terjadi dengan sebutan hoax.

Ada banyak hoax yang beredar dimasyarakat Indonesia, namun secara umum ada sekitar sepuluh jenis hoax yang umum beredar dan mendapatkan respons dari masyarakat. Jenis hoax tersebut dapat terlihat jelas pada gambar dibawah ini:

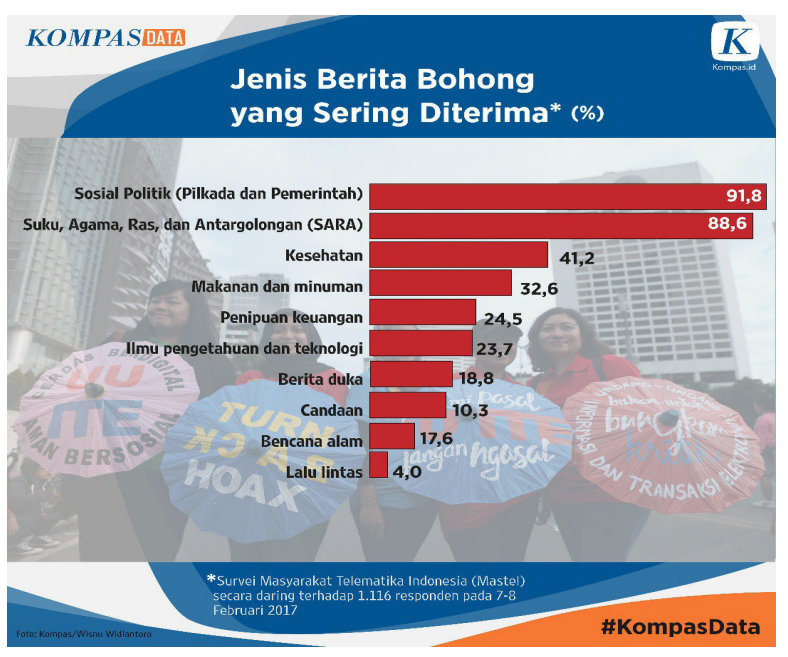

Sumber gambar: kompas data ${ }^{18}$

\footnotetext{
${ }^{18}$ http://hai.grid.id, Diakses pada tanggal 7 Januari 2019.
} 
Dari hasil survey di atas dapat diketahui bahwa berita hoax yang paling laku di masyarakat adalah yang berkaitan dengan sosial politik (pilkada/pemerintah) yang mencapai 91,8\% dan kemudian disusul berita hoax yang berkaitan dengan sentimen SARA yang mencapai $88,6 \%$. Data ini diambil dari 1.116 responden pada tahun 2017. Setiap responden diberikan masing masing 10 pertanyaan terkait berita hoax mulai dari pertanyaan berkaitan dengan sosial politik (pilkada/pemerintah) hinga pertanyaan yang berkaitan dengan hoax lalu lintas.

\section{Penyebab Munculnya Hoax}

Ada beberapa faktor yang menjadi penyebab hoax muncul dan tersebar dimasyarakat, faktor faktor tersebut antara lain: pertama, faktor perkembangan teknologi dan informasi. Kemudahan yang ditawarkan oleh teknologi sering disalah gunakan oleh oknum oknum yang tidak bertanggung jawab. Peneliti Populi Center Rafif menyatakan informasi yang mengalir di media sosial yang ada tidak semuanya fakta karena media sosial merupakan pasar bebas yang informasi didalamnya tak tersaring. ${ }^{19}$ Kondisi ini diperparah dengan rendahnya literasi publik terhadap pesan-pesan di media sosial, sehinga berita berita hoax yang beredar banyak dibagikan di media sosial pribadinya. ${ }^{20}$ Kedua, faktor politik. Kondisi politik suatu daerah sangat mempengaruhi tersebarnya berita berita hoax. Daerah yang akan menyelengarakan pesta demokrasi sangat rentan menjadi sasaran berita hoax.

Menurut Danarka Sasongko, Dosen Ilmu Komunikasi Universitas Atmajaya Yogyakarta, fenomena merebaknya berita berita hoax di media sosial meningkat tajam menjelang pesta demokrasi baik pemilihan kepala daerah maupun pemilihan umum. ${ }^{21}$ Berita hoax sengaja disebar

\footnotetext{
${ }^{19}$ www.tempo.co, Diakses pada tanggal 8 Januari 2019.

${ }^{20}$ Danarka Sasongko, Dosen Ilmu Komunikasi Universitas Atmajaya Yogyakarta, Diakses dari www.tempo.co. pada tanggal 8 Januari 2019.

${ }^{21}$ www.tempo.co. Diakses pada tanggal 8 Januari 2019.
}

untuk dijadikan senjata dalam menjatuhkan lawan politiknya, sehinga pihak lawannyapun melakukan hal yang sama juga. Black campaign seringkali dijadikan senjata politik yang efektif karena kultur politik masyarakat kita belum terlalu matang juga.

Ketiga, faktor ketegasan hukum. Supremasi hukum mutlak dibutuhkan agar hukum bisa efektif diterapkan. Sebagus apapun hukum yang ada apabila dalam implementasinya masih tebang pilih maka hukum tersebut tidak akan efektif dalam mengatasi kejahatan. Demikian juga dalam kasus penyebaran berita hoax, hukum harus bisa menindak sampai keakar akarnya. Bukan hanya pembuat penyebaran dan pembuat berita hoax saja yang dihukum tapi dalang dibalik penyebaran berita hoax tersebut harus diberikan sanksi juga. Ketidak tegasan dalam menindak pihak pihak yang terlibat dalam kasus hoax tersebut bisa menyebabkan berita hoax yang lain tumbuh dengan subur.

Keempat, faktor ketidaktahuan. Kadiv Humas Polri Irjen Setyo Wastito menyatakan bahwa salah satu penyebab beredarnya berita hoax adalah ketidaktahuan dari orang yang menshere berita tersebut adalah berita hoax. Hal ini terjadi karena berita tersebut diperoleh dari orang yang ia percaya sehinga ia menshere tanpa melakukan kroscek terlebih dahulu padahal orang tersebut juga memperoleh dari sumber yang tidak pasti kebenarannya. Menurut setyo, alasan orang menyebarkan hoax karena berita itu berasal dari orang yang dipercaya sekitar $48 \%$ sedangkan $31 \%$ orang yang menyebarkan berita tersebut merasa bahwa informasi itu bermanfaat, kemudian $18 \%$ mengira bahwa berita yang disebar itu benar dan sekitar $3 \%$ menyebarkan berita hoax karena merasa ingin jadi yang pertama dalam menyebarkan berita itu. ${ }^{22}$

Kelima, adanya niat jahat. Motif ini merupakan motif yang sangat berbahaya, karena

22 Kadiv Humas Polri Irjen Setyo Wastito, di DPP Perkumpulan Gerakan Kebangsaan (PGK), Jalan Duren Tiga, Pancoran, Jakarta Selatan, Senin (15/10/2018). Didownloud newsdetik.com, pada tanggal 7 Januari 2019s 
tujuan ia menyebarkan berita hoax ingin menimbulkan keresahan, ketakutan, konflik dan perpecahan ditengah tengah masyarakat. Misalnya berita penculikan anak kecil yang viral di pesan pribadi atau media sosial membuat banyak orangtua resah, khawatir dan ketakutan. Menurut Komisi Perlindungan Anak Indonesia (KPAI) beberapa pesan tentang penculikan anak memang ada yang benar, namun ada sebagian besar yang hoax. Sehinga menurut KPAI lebih baik berita tersebut tidak disebarkan kembali. ${ }^{23}$

\section{Hoax Dalam Tinjauan Hukum Islam}

Berita hoax di zaman Rasullullah pernah terjadi juga bahkan menimpa istri beliau, yakni Sayyidah Aisyah, hal ini sebagaimana hadis yang diriwayatkan oleh Imam Bukhari,

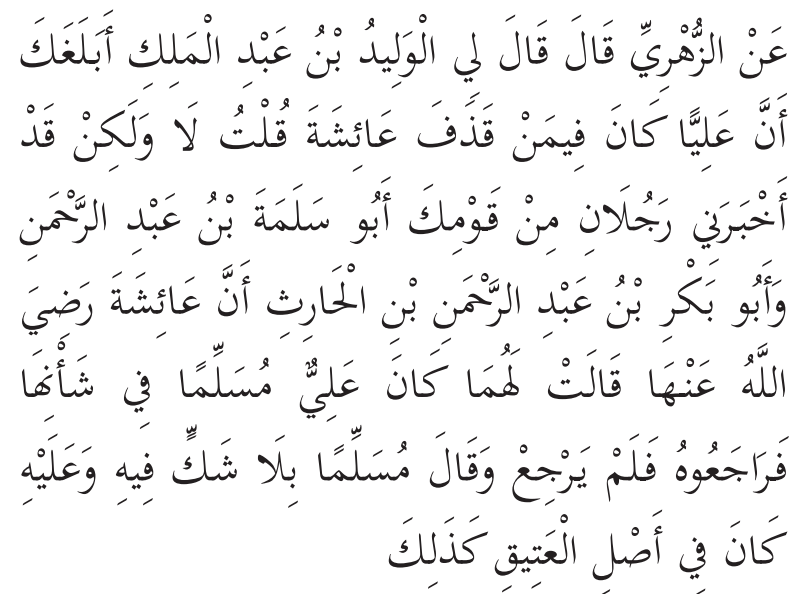

Dari Az Zuhriy, ia berkata bahwa Walid bin Abdul Malik telah bertanya kepadaku; Apakah Ali adalah termasuk orangyang menuduh sayyidah 'Aisyah telah berselingkuh?' Aku jawab; "Tidak. Akan tetapi dua orang dari kaummu yakni Abu Salamah bin Abdurrahman dan Abu Bakr bin Abdurrahman bin Al Harits yang mengabarkan kepadaku, bahwa sayyidah Aisyah radliallahu 'anha pernah berkata kepada keduanya bahwa Ali menerima (berita hoax ini). Lalu mereka kembali bertanya tapi Az-Zubri, namun ia tidak menjawabnya. Dia berkata; "Musalliman (menerima) tanpa diragukan lagi”. Demikian juga makna pada asal katanya. (HR. Imam Bukhari) 2019
Hadis yang selanjutnya adalah:

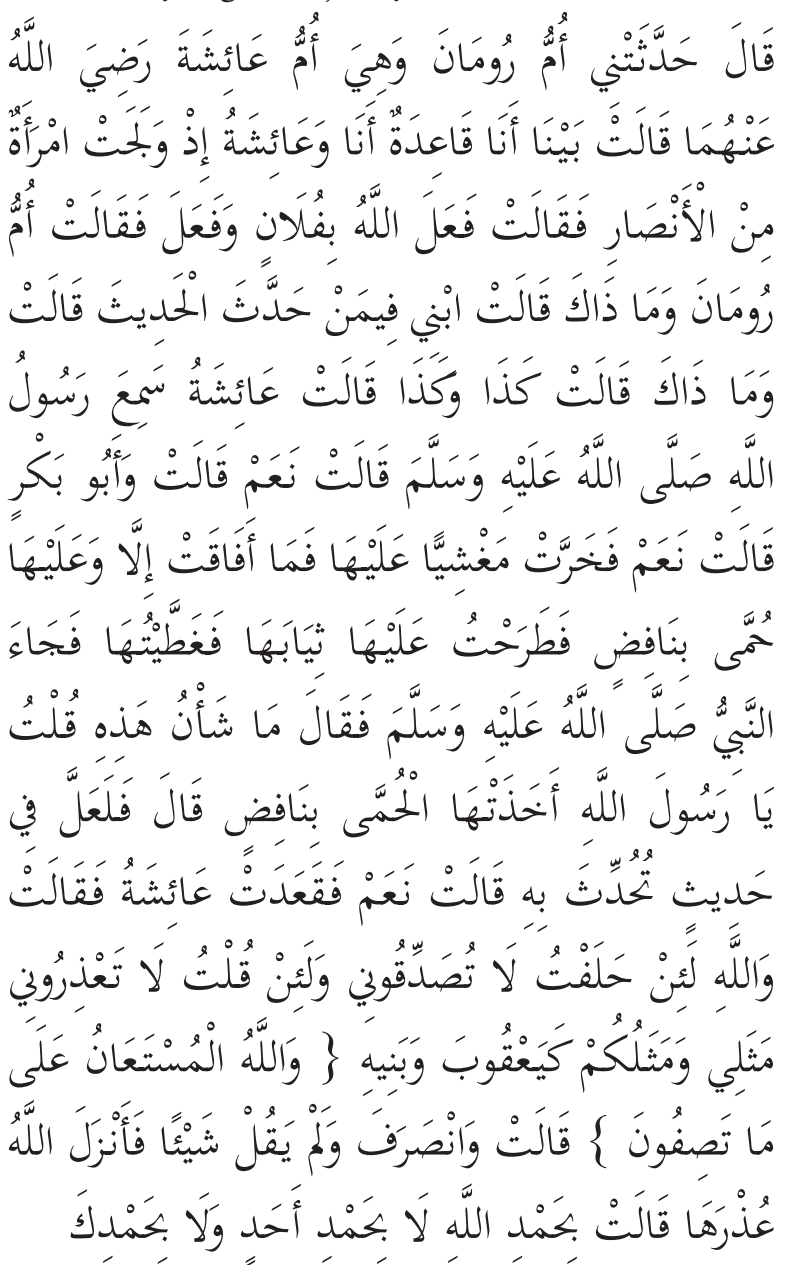

Ummu Ruman ibunya 'Aisyah radliallahu' 'anhuma telah menceritakan kepadaku bahwa ia berkata; "Saat aku dan sayyidah 'Aisyah duduk duduk, tibatiba seorang wanita Anshar datang seraya berkata; "Semoga Allah berbuat terhadap fulan dan pasti berbuat." Maka Ummu Ruman bertanya; "Ada apa sebenarnya?". Wanita itu berkata; "Putraku termasuk orang yang menyebarkan berita ini." Aisyah bertanya; "Berita apa itu?". Wanita itu menjawab; "Begini dan begini". Aisyah bertanya; "Apakah Rasulullah saw telah mendengarnya?". Dia menjawab; "Ya". Aisyah bertanya lagi; "Dan Abu Bakr?". Dia menjawab; "Ya". Maka 'Aisyah jatuh pingsan dan tidak sadarkan diri melainkan setelah menderita demam yang sangat tinggi. Aku lalu menyelimutinya dengan pakainnya dan menutupinya hingga Nabi saw datang dan bertanya: "Ada apa dengannya?". Aku jawab; "Wahai Rasulullah, dia terserang demam." Beliau bersabda: "Ini pasti karena berita bohong yang engkau ceritakan." Ummu Ruman berkata; "Ya 
benar." Kemudian Aisyah duduk dan berkata; "Demi Allah, seandainya aku bersumpah, engkau tidak akan mempercayaiku dan seandainya aku katakan tidak, maka kalian akan menudubku, permisalanku dengan kalian seperti Yàqub 'alaibis salam dengan anak-anaknya ketika dia berkata: "Dan Allah sajalah yang dimohon pertolongan-Nya terhadap apa yang kamu ceritakan." QS Yusuf; 18. Ummu Ruman berkata; "Lalu beliau berlalu tnpa mengucapkan sepatah katapun. Kemudian Allah menurunkan firman-Nya yang menjelaskan bukti sucinya diri Aisyah dari segala tuduhan. Saat itu 'Aisyah berkata; "(Segala puji bagi Allah) dan ini karena Allah Yang Maha Terpuji dan seseorang tidak layak mendapat pujian dan tidak pula engkau. (HR. Imam Bukhari)

Gara-gara tersebarnya berita hoax ini, sayyidah 'Aisyah dan Rasulullah merasa tidak nyaman dan gelisah hingga akhirnya Allah menurunkan sepuluh ayat Alquran perihal berita hoax ini. Allah Swt berfirman dalam surat al-Nur ayat 11 sampai 20:

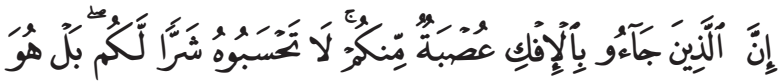

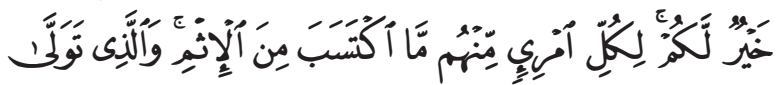

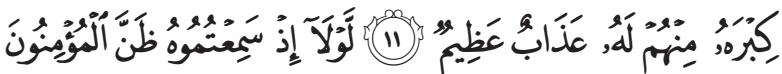

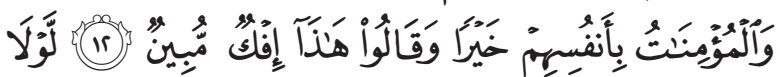

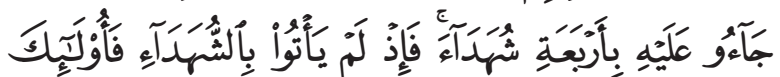

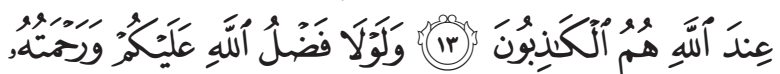

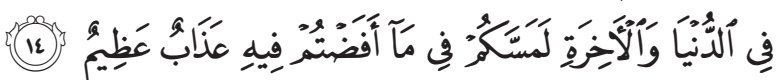

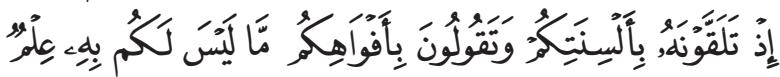

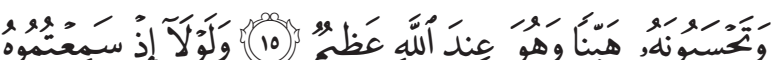

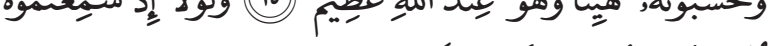

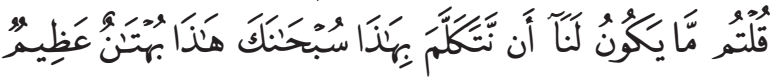
(iv)

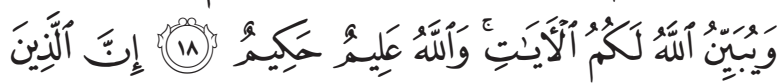

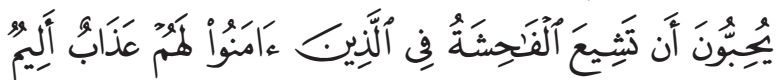

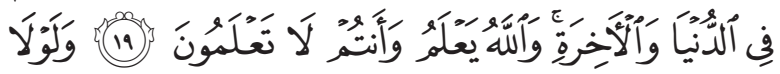

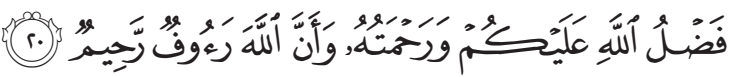
Sesungguhnya orang-orang yang membawa berita bohong itu adalah dari golongan kamu juga. Janganlah kamu kira bahwa berita bohong itu burukbagikamubahkaniaadalahbaikbagikamu, tiap-tiap orang dari mereka mendapat balasan dari dosa yang dikerjakannya. Dan siapa di antara mereka yang mengambil bagian terbesar dalam penyiaran berita bohong itu, maka baginya azab yang besar. Mengapa di waktu kamu mendengar berita bohong itu orang-orang Mukminin dan Mukminat tidak bersangka baik terhadap diri mereka sendiri, dan (mengapa tidak) mengatakan, "Ini adalah berita bohong yang nyata." Mengapa mereka (yang menuduh itu) tidak mendatangkan empat orang saksi atas berita bohong itu? Karena mereka tidak mendatangkan saksi-saksi, maka mereka itu di sisi Allah adalah orang-orang yang dusta. Sekiranya tidak ada kurnia Allah dan rahmat-Nya kepada kamu semua di dunia dan di akhirat, niscaya kamu ditimpa azab yang besar, akibat pembicaraan kamu tentang berita bohong itu. (Ingatlah) di waktu kamu menerima berita bohong itu dari mulut ke mulut dan kamu katakan dengan mulutmu apa yang tidak kamu ketahui sedikit juga, dan kamu menganggapnya suatu yang ringan saja, padahal dia di sisi Allah adalah besar. Dan Mengapa kamu diwaktu mendengar berita bohong itu tidak mengatakan, "Kita sama sekali tidak pantas untuk mengucapkan ini, Maha Suci Engkau (Ya Rabb kami), ini adalah dusta yang besar." Allah memperingatkan kamu agar (jangan) kembali memperbuat yang seperti itu selama-lamanya, jika kamu orang-orang yang beriman. Dan Allah menerangkan ayat-ayat-Nya kepada kamu. Dan Allah Maha mengetahui lagi Maha Bijaksana. Sesungguhnya orang-orang yang ingin agar (berita) perbuatan yang amat keji itu tersiar di kalangan orang-orang yang beriman, bagi mereka azab yang pedih di dunia dan di akhirat dan Allah mengetahui, sedang, kamu tidak mengetahui. Dan sekiranya bukan karena kurnia Allah dan rahmat-Nya kepada kamu semua, dan Allah Maha Penyantun dan Maha Penyayang, (niscaya kamu akan ditimpa azab yang besar). (QS. Al-Nûr/24:11-20)

Dengan turunnya ayat ini, maka permasalahan ini pun menjadi jelas, fitnah yang 
ditujukan kepada sayyidah aisyah pun sudah hilang dengan sendirinya. Baik Rasulullah saw, Ummul Mukminin 'Aisyah ra. maupun kaum Muslimin merasa lega. Namun, sebagian kaum muslimin merasa berang dengan orang-orang yang ikut andil dalam mencoreng nama baik ummul Mukminin. Bahkan sampai-sampai Abu Bakar al-Shiddiq tersulut emosinya juga ketika tahu bahwa Misthah bin Utsâtsah, sepupu beliau yang selama ini dibantu ekonominya oleh beliau ternyata ikut andil dalam menyebarkan berita hoax yang telah melukai hati Rasulullah saw dan seluruh kaum Muslimin ini. Bahkan sampai beliau bersumpah untuk tidak akan membantunya lagi. Akibat sumpah beliau ini, lalu Allah Swt. menurunkan firman:

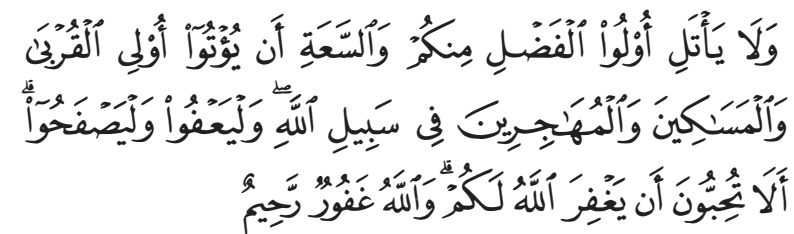

"Dan janganlah orang-orang yang mempunyai kelebihan dan kelapangan di antara kamu bersumpah bahwa mereka (tidak) akan memberi (bantuan) kepada kaum kerabat(nya), orangorang yang miskin dan orang-orang yang berhijrah di jalan Allah, dan hendaklah mereka mema'afkan dan berlapang dada. Apakah kamu tidak ingin Allah mengampunimu? dan Allah adalah Maha Pengampun lagi Maha Penyayang" (QS.AlNûr/24: 22).

Setelah ayat ini turun, akhirnya Abu Bakar ra. membantu Misthah kembali karena mengharap ampunan dari Allah Azza wa Jalla. Asbabun nuzul ayat ini lah yang menjadi dasar sebagian ulama untuk memberikan maaf kepada pelaku dan penyebar hoax apabila diduga kuat orang tersebut sudah bertaubat dan berjanji tidak akan mengulangi perbuatanya.

Selain itu, dalam ayat-ayat di atas, Allah mencela orang orang yang terperangkap dalam jebakan hoax yang sengaja disebar oleh orangorang munafik. Allah juga memuji kaum Mukminin yang tidak termakan isu hoax ini dan menyikapinya dengan bijak sembari menyakini kedustaan berita hoax ini. Allah juga mengajarkan kepada kaum muslimin bahwa ketika mendapatkan berita yang tidak jelas, harus dikroscek dulu.

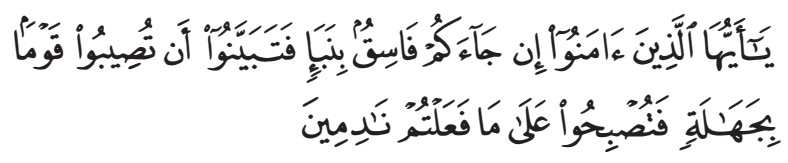

Hai orang orang yang beriman, apabila orang munafik datang dengan membawa sebuah berita maka bertabayunlah (kroscek kebenarannya), agar jangan sampai kalian menimpakan suatu bahaya kepada suatu kaum karena dasar kebodohan, kemudian akhirnya kalian menjadi menyesal atas perlakukan kalian. (QS. Al-Hujarat: 6)

Ayat di atas menegaskan bahwa berita berita yang tidak jelas sumbernya perlu dikroscek terlebih dahulu kebenarannya agar tidak menimbulkan fitnah maupun bencana ditengah tengah masyarakat. Namun faktanya, sering kali orang terbakar emosi ketika mendapatkan berita hoax tanpa sempat melakukan kroscek terlebih dahulu. Sehinga wajar jika Allah memuji orang yang tidak termakan berita hoax. Diantara sahabat Nabi yang dipuji dengan turunnya surat al-Nur adalah sahabat Abu Ayyub al-Anshari ra. Beliau bisa mendapatkan pujian karena bukan hanya tidak mempercayai berita ini bahkan beliau mengatakan tidak pantas berita seperti ini diucapkan oleh seorang mukmin. Kisah beliau ini diriwayatkan oleh Imam Bukhari rahimahullah dalam sebuah hadits yang memberitakan bahwa ketika beliau mendengar berita hoax ini, beliau Radhiyallahu anhu mengatakan: kita sama sekali tidak pantas untuk mengucapkan ini, Maha Suci Engkau (Ya Rabb kami), ini adalah dusta yang besar [HR. Bukhari, al Fath, 28/110, no. 7370]

Setelah perkara berita hoax yang menimpa Sayyidah Aisyah ini menjadi jelas, Rasulullah saw kemudian menuntaskannya dengan memberikan sanksi kepada mereka yang terlibat dalam kasus ini. ${ }^{24}$

\footnotetext{
${ }^{24}$ Almanhaj.or.id, Diakses pada tanggal 10 Januari 2019
} 


\section{Sanksi Ta'zir Bagi Pembuat Dan Penyebar Hoax}

Ketika memberikan sanksi ta'zir kepada pembuat dan penyebar hoax tidak bisa dilakukan secara sembarangan melainkan harus memperhatikan beberapa hal penting antara lain:

Pertama, dilihat dari unsur perbuatannya termasuk tindak pidana atau tidak, yakni dengan melihat unsur formil, matiril dan moril. Apabila perbuatan tersebut sudah memenuhi ketiga unsur tersebut maka sudah bisa ditetapkan sanksi ta'zirnya. Unsur moril dengan melihat apakah pembuat masuk kategori orang yang cakap melakukan tindakan hukum atau belum. Apabila pembuat hoax masih anak dibawah umur atau orang yang cacat mental maka tidak bisa dijatuhkan sanksi ta'zir. Yang bisa dijatuhi sanksi ta'zir hanya orang yang sudah abli tasaruf (cakap melakukan tindakan hukum)

Kedua, motif pembuat dan penyebar hoax tersebut.

\begin{tabular}{|c|c|c|c|c|}
\hline \multirow{2}{*}{ No } & \multirow{2}{*}{$\begin{array}{l}\text { Motif } \\
\text { Menyebar } \\
\text { Hoax }\end{array}$} & \multicolumn{3}{|c|}{ Sanksi Ta'zir } \\
\hline & & Ringan & Sedang & Berat \\
\hline 1 & $\begin{array}{l}\text { Perkembangan } \\
\text { teknologi dan } \\
\text { informasi }\end{array}$ & $\checkmark$ & & \\
\hline 2 & Politik & & & $\checkmark$ \\
\hline 3 & $\begin{array}{l}\text { Ketegasan } \\
\text { hukum }\end{array}$ & & $\checkmark$ & \\
\hline 4 & Ketidaktahuan & $\checkmark$ & & \\
\hline 5 & $\begin{array}{l}\text { Adanya niat } \\
\text { jahat }\end{array}$ & & & $\checkmark$ \\
\hline
\end{tabular}

Dari kelima motif di atas, motif pembuat dan penyebar hoax karena adanya niat jahat dan politik, diberikan sanksi terberat. Ini karena memang si pembuat memiliki tujuan membuat keresahan, kegaduhan, dan kekacauan di masyarakat. Kekacauan ini sengaja dimunculkan agar ia mendapatkan keuntungan, baik dari sisi politis maupun ekonomis. Sedangkan pembuat dan penyebar hoax dengan alasan tidak adanya ketegasan hukum, diberikan sanksi sedang. Ini karena kesalahan tersebarnya hoax tidak hanya berasal dari pihak penyebar saja, tapi juga dari pihak pembuat, penegak hukum, dan pengawas. Sedangkan pembuat dan penyebar hoax dengan motif perkembangan teknologi dan informasi serta motif ketidaktahuan, diberikan sanksi paling ringan. Ini karena adanya unsur khatha' (salah duga) yang sekiranya ia mengetahui kalau berita tersebut adalah hoax, niscaya ia tidak akan menyebarkannya.

\section{Penutup}

Pemberian sanksi penyebar hoax dalam istinbath ahkam akan diberikan tidak sama antara satu pelaku dengan yang lainnya. Namun, harus melihat latar belakang penyebabnya terlebih dahulu. Ada tiga kategori dalam pemberian sanksi ta'zir, yakni sanksi ringan, sedang, dan berat. Sanksi ringan diberikan kepada penyebar hoax dengan motif ketidaktahuan dan korban perkembangan teknologi dan informasi. Sedangkan pemberian sanksi sedang diberikan kepada penyebar hoax dengan motif tidak adanya ketegasan hukum. Pemberian sanksi sedang ini karena kesalahan tersebarnya hoax tidak hanya berasal dari penyebar saja, tapi juga dari pihak pembuat, penegak dan pengawas. Kemudian penyebar hoax yang memiliki motif adanya niat jahat dan politik, diberikan sanksi terberat karena memang si penyebar memiliki tujuan membuat keresahan, kegaduhan, dan kekacauan di masyarakat.

\section{Pustaka Acuan}

Andiko, Toha, "Reinterpretasi Sanksi Pidana Islam (Studi terhadap Pemikiran Prof. KH. Ibrahim Hosen", LML), Madania: Jurnal Kajian Keislaman, Vol. 18, No. 2, (2014).

Andiko, Toha, "Sanksi Bagi Pemberi Dan Penerima Gratifikasi Perspektif Hukum Pidana Islam”, Jurnal Qiyas, Vol. 1, No. 1, (2016).

Audah, Abd al-Qadir al-. Al-Tasyri Al-Jinäi AlIslami, Maktabah Syamilah Versi 7 G \& 14 G, Jld 1. 
Bisri, Cik Hasan. Model Penelitian Figh, Bogor: Kencana, 2003, cet. ke-1.

Bisri, Cik Hasan. Pilar-Pilar Penelitian Hukum Islam dan Pranata Sosial, Jakarta: PT. Raja Grafindo Persada, 2004, cet. ke-1.

Craig, Silverman. Journalism: A Tow/Knight Report."Lies, Damn Lies, and Viral Content". Columbia Journalism Review, (2015).

Departemen Agama RI. Qur'an dan Terjemahannya, Bandung: Pustaka Pelajar, 2015.

Djazuli, A. Fiqh Jinayah, Jakarta: Rajagrafindo Persada, 2000.

Hakim, Rahmat. Hukum Pidana Islam. Bandung: CV Pustaka Setia, 2000, cet. ke-1.

Kasiram, Moh. Metodologi Penelitian KualitatifKuantitatif, Malang: UIN-Maliki Press, 2008, cet. ke-1.
Wijayanti, Sri. "Arti kata Hoax - Kamus Besar Bahasa Indonesia (KBBI) Online".

Zuhaili, Wahbah al-. Fiqh al-Islami wa Adillatuhu, Damaskus: Dar a-Fikr, 2004, cet. ke-14, Jilid 7.

\section{Internet:}

http: almanhaj.or.id.

http://bangka.tribunnews.com.

http://hai.grid.id.

https://kominfo.go.id.

https://nasional.kompas.com.

www.kbbionline.com.

www.liputan6.com.

www.tempo.co.id. 